\title{
Correlation between the Prescribed Didactic Treatment of the Teacher's and Perceptions of Congolese Students during Physical Education Lesson
}

\section{David Sylvain Mabassa1*, Gorgon Lembe1, Hygin Bellarmin Elenga², Aimé Simplice Ambeto1, Fernandes Balou Gabin Christophe ${ }^{1,3}$, Jean Itoua Okemba ${ }^{1,3}$}

\author{
${ }^{1}$ Laboratory of Didactics of Physical Education, Higher Institute of Physical Education, Marien Ngouabi University, \\ Brazzaville, Congo \\ ${ }^{2}$ Laboratory of Human and Social Sciences, Physical Education, Higher Institute of Physical Education and Sports, \\ Marien Ngouabi University, Brazzaville, Congo \\ ${ }^{3}$ Laboratory for Studies and Research in Adapted Physical Activities, Higher Institute of Physical Education and Sports, \\ Marien Ngouabi University, Brazzaville, Congo \\ Email: ^dmabassa@googlemail.com
}

How to cite this paper: Mabassa, D. S., Lembe, G., Elenga, H. B., Ambeto, A. S., Christophe, F. B. G., \& Okemba, J. I. (2020). Correlation between the Prescribed Didactic Treatment of the Teacher's and Perceptions of Congolese Students during Physical Education Lesson. Advances in Physical Education, 10, 217-232.

https://doi.org/10.4236/ape.2020.103019

Received: May 27, 2020

Accepted: August 1, 2020

Published: August 4, 2020

Copyright $\odot 2020$ by author(s) and Scientific Research Publishing Inc. This work is licensed under the Creative Commons Attribution International License (CC BY 4.0).

http://creativecommons.org/licenses/by/4.0/

\begin{abstract}
The purpose of this study is to assess the correlation between the didactic treatment prescribed by the PE teacher and the characteristics perceived by the students during the course of the PSE lesson. In other words, assess the perceptions and the effects of feedback perceived by the teacher's students, according to the level and physical skills of the students. The study was conducted with 151 students and 10 PE teachers, all of whom are attending colleges. The average age of the students was $14.3 \pm 1.85$ years and that of the teachers was $35 \pm 2.41$ years, with $10 \pm 0.8$ years of teaching experience. A questionnaire (CFQ; Allen, \& Howe, 1998; Amorose \& Horn, 2000), based on the observation grid (CBAS; Smith et al., 1977), was sent to students asking them to evaluate Frequency their teacher reacts to their benefits by this or that feedback. The results show an inequality of inter-sex treatment. Girls perceive, receive more technical feedback and say they initiate more interaction with the teacher. On the other hand, boys perceive, receive more criticism and feel more ignored by the teacher than girls. And then the perceptions of the teacher's feedback affect the physical competence of the girls more than those of the boys. This study appreciated the perceptions and effects of feedback received by students from the teacher and the level of skills, justifying the inclusion in the learning of PE students.
\end{abstract}




\section{Keywords}

Didactic Strategies, Perceptions Pupil, Teacher, Feedback, Physical Education

\section{Introduction}

Teaching-learning is a didactic process which allows the teacher to organize learning tasks in order to make them more accessible and more assimilable to pupils. It is in this context that Ria (2014) emphasizes that knowledge is no longer transmitted to the student: it is devoted to him, that is to say made available to him through what the author calls "the practical school situation". This educational situation, according to Le Ny (2017), has four poles and three types of relationships that constitute the educational triangle. The four poles of the educational situation are: the teacher, the student, knowledge and the environment. Thus, the teacher's interventions must take into account the diversity of the students. Taking this diversity into account is one of the ten professional skills to be acquired by teachers. It is in this sense that several studies have been conducted on the representations of students during lessons (Nadler \& Nadler, 1990; Crawford \& MacLeod, 1990; DeVoe, 1991; Auster \& Mc Rone, 1994; Condravy et al., 1998; Brady \& Eisler, 1999). For example, Crawford and MacLeod (1990) with a sample of 700 students, from 31 classes, used a modified version of the questionnaire from Jenkins et al. (1983). They reported that boys perceive themselves to be more active, say that they solicit the teacher even if they do not raise their hands, and perceive that teachers answer their questions more favorably than those of girls, who perceive engaging less in classroom exchanges than boys.

Furthermore, Nadler and Nadler (1990) using their own questionnaire with 272 students reported that boys do not say they initiate more interaction or receive more support than girls. However, Auster and Mc Rone (1994) interviewed 132 students about their participation in class and found that boys reported participating more in class than girls. Unfortunately, Brady and Eisler (1999) did not show a difference in perceptions of the classroom climate for girls and boys.

In physical education $(\mathrm{PE})$, the paradigm of mediating processes specifies that the teacher PE does not directly influence the student's success, but rather affects the way of thinking and behaving in the student. If student knowledge is seen as an important variable, the way the student thinks is problematic because it cannot be observed directly. For example, it is known that students are motivated in physical education and fully engage in learning when the physical and sports activity taught comes into resonance with their representations and partly satisfies their motives for acting. In addition to the cognitive function (understanding and explaining reality) attributed to representations, they have an orientation function by prescribing practices in a certain way for teachers. In the area of education, Condravy et al. (1998) point out that most studies do 
not examine student representations of interactions with the teacher. Studies on representations are few, but seem to largely support research by video observation. However, in Congo (Brazzaville), only one study on the impact of student representations on teaching strategies in physical education has been found in the literature (Mabassa, 2015). The author which has examined the representations of girls and boys of feedback from the PE teacher, showed that through his interviews with the 150 students randomly selected from the classes observed in PE, that girls and boys perceive differently didactic treatment of PE teacher. In fact, students perceive that the teacher encourages them, helps them, berates them, asks them to answer questions and does exercise demonstrations and speaks to them. Also, the PE teacher interacts more with the boys on all categories of feedback encoded (congratulations, questions, information and reviews). He gives more behavioral criticism to boys in order to control them. The majority of students receive fair treatment from the PSE teacher. But, the teacher provides more verbal interactions such as praise and information for girls, more criticism for boys, and as many questions for both genders.

Consequently, our study answers a double question: How do student perceptions influence the teaching strategies of physical education teachers? Knowing that the declarations of intention or the injunctions of the teachers have an impact on the behaviors of the students in physical education lesson, what are the didactic strategies adopted by the teachers so that all the students want to learn?

Thus, the effect of the feedback given by the teacher on the physical performance of the pupil in PE is not known. It is to fill this gap that this work was undertaken, in order to assess the representations of Congolese students correlative to the didactic treatment prescribed by the PE teacher.

\section{Materials and Methods}

\subsection{Design Study and Sampling}

The study was conducted in Congo-Brazzaville in the general education colleges. The choice of these colleges was justified by the following criteria: To be a public college, existence of a complete cycle from the sixth to the third, regular practice of the PE at the rate of 2 hours weekly, presence of the sports facilities. The source population was 2635 students. After drawing, 581 students were selected to participate in the experimentation. To this end, four inclusion criteria were chosen for the sample: To be new in class, to be assiduous in the course of PE, to be in good health certified by a medical certificate, to have replied to the questionnaire. Following these requirements, 151 students (53 girls and 98 Boys) were selected. The mean age of pupils was $14.3 \pm 1.8$ years old and from grades 6, 5, 4 and 3. As for PE teachers, the selection was made according to the following criteria: 1) out of the Higher Institute of Physical Education and Sports; 2) to be an assistant professor of PE; 3) to have a professional experience of at least 10 years. Thus, a sample of 10 teachers of 20 ( 6 women and 4 men) aged $35 \pm 2.41$ years, having $10 \pm 0.8$ years of teaching experience was retained. 


\subsection{Experimental Procedure}

The feedbacks of the PE teacher and the perceptions of the pupils, their physical skills and certain sociodemographic characteristics (age, sex, extracurricular sport practice, parents' profession) were measured. Anonymity was guaranteed, only the first name and date of birth were identified in order to find the PE note provided by the teacher.

\subsection{Measurement Tools}

A questionnaire (QFC; Allen \& Howe, 1998; Amorose \& Horn, 2000), based on the observation grid (CBAS; Smith et al., 1977) was addressed to students, asking them to assess how often their teachers respond to their performance through feedback.

The pupil's perceptions sur le temps accordé by the teacher during the PE lessons, ont fait l'objet de four items on their a priori representions à partir de two sub-factors: 1) the frequency (the number of times The teacher goes to the student.); 2) the duration of interactions (time spent in interactions with the pupil).

- Perceived competence: in order to measure the perceived competence of pupils in PE, a questionnaire of four items already employed in French research with teenagers by Sarrazin et al. (1995) A been used [in PE, I feel rather... (1) Very bad, (7) Very good, "in PE, when I compare myself to others, I find myself..." (1) Very bad, (7) very good. The average of the replies was therefore calculated and considered as an indicator of the perceived competence in PE. The internal consistency of this variable was satisfactory [ $\alpha=0.88]$.

- The PE score: It was considered an indicator of success or skill of the pupil elaborated on 20 points. The teacher's assessment was carried out on both physical performances, the student's driving skills to achieve the student's performance, knowledge and progress. But, we are aware that the use of such a measure is subject to the influence of various biases on the part of the teacher (David, 2000). However, Trouilloud et al. (2002) found a correlation $[r=$ 0.65 ] between the student's physical tests and the teacher's final evaluation. The middle of these remarks was calculated and considered as an indicator of the pupil's level in PE, referred to as the pupil's level in PE. The internal consistency of three notes was satisfactory $[\alpha=0.73]$.

- Sociodemographic data: The characteristics of the pupils (age, sex, occupation of parents, sports practice outside the school) were collected on the questionnaire. The pupil was asked whether or not he practised physical and sporting activity outside the school, the framework in which he practised it (club, team, School Association, Free), the sport practiced and the number of hours per week he devoted to it. We treated this variable as a continuous variable where we took into account the number of hours per week.

\subsection{Statistical Analysis}

A structural factor Analysis allowed to identify the structure and factorial validi- 
ty of the student perceptions Questionnaire. For the teacher feedback (QPFE), a major component factor analysis (PCR) was conducted. In accordance with the rule of extraction of factors proposed by Guttman (1954), the number of factors extracted from the analysis corresponds to the number of eigenvalues greater than 1. In addition, each factor accounts for at least $5 \%$ of the variance explained. However, the structural Factor Analysis (PCR) shows that student perceptions were divided into 8 factors including 41 items and explaining $60 \%$ of the variance. The details of the factorial structure of the questionnaire can be found in Table 1.

- The first factor was composed of 10 items representing the perceptions of the teacher's feedback after a good performance (congratulations). The items translated positive teacher information, either verbal or nonverbal, or with or without technical confirmation.

- The second factor was characterized by 3 items, non-reinforcements of the teacher when the student was successful.

- The third factor grouped the 3 items reflecting the students' requests to the teacher to show him his good performances.

- The fourth factor represented 4 items, feedbacks describing technical information how to correct his mistake.

- The fifth factor brought together 4 items, the teacher's encouragement in response to the student's poor performance.

- The sixth factor referred to the critics and grouped 11 items representing a negative response perceived by the pupil, following his poor realization. The items translated information both verbal and non-verbal, with or without corrective information.

- The seventh factor represented 3 items, when the teacher ignored the student's failures.

- The eighth factor at 3 items, which represented the student's solicitations towards the teacher to ask for help.

You will talk to your teacher to ask for help. The responses obtained in the Table 1 montrent that all factors have an acceptable level of internal consistency, variance, and own value (Cronbach, 1951), with the exception of 7ème factor: No reinforcement in a failure situation $[\alpha=0.40$; variance $=2 \%$; own value $=$ 0.79]. Therefore, this factor was not retained for the essential suite.

\section{Results}

\subsection{Analysis of the Correlation Matrix of Variables}

In order to control teachers who talk a lot, the data were standardized by class. Analysis correlations between the variables were conducted and represented in Table 2. The reading of the results obtained in Table 2 reveals that the student's physical competence, PE score, and feedback are correlated with the gender of the pupil, except congratulations and time invested. 
Table 1. Factor structure of the perceived teacher feedback questionnaire (QFPE).

\begin{tabular}{|c|c|c|c|c|c|}
\hline & Situations & $\begin{array}{l}\text { Own } \\
\text { value }\end{array}$ & $\begin{array}{c}\% \\
\text { variance }\end{array}$ & $\begin{array}{l}\text { consistency } \\
(\alpha=0.87)\end{array}$ & Items \\
\hline \multirow{12}{*}{ Factor 1} & \multirow{4}{*}{$\begin{array}{c}\text { Verbal } \\
\text { congratulations }\end{array}$} & \multirow{12}{*}{6.52} & \multirow{12}{*}{14} & 0.86 & $\begin{array}{l}\text { Congratulates you, for example: } \\
\text { "Well done!" }\end{array}$ \\
\hline & & & & 0.74 & $\begin{array}{l}\text { Approves, for example: } \\
\text { "Excellent work!" }\end{array}$ \\
\hline & & & & 0.75 & $\begin{array}{l}\text { Compliments you, for example: } \\
\text { "well done!" }\end{array}$ \\
\hline & & & & 0.78 & $\begin{array}{l}\text { Congratulates you, for example: } \\
\text { "Good job!" }\end{array}$ \\
\hline & & & & 0.51 & $\begin{array}{l}\text { Supports you by giving you } \\
\text { indications, for example: } \\
\text { "That's good! You really } \\
\text { extended your arm to } \\
\text { catch the plug!" }\end{array}$ \\
\hline & $\begin{array}{l}\text { Congratulations } \\
\text { with technical } \\
\text { feedback }\end{array}$ & & & 0.66 & $\begin{array}{l}\text { Congratulate you and } \\
\text { remember what you did well! } \\
\text { For example: "Well done!" } \\
\text { You looked at the ball! }\end{array}$ \\
\hline & & & & & $\begin{array}{l}\text { Reward you for saying, } \\
\text { for example: }\end{array}$ \\
\hline & & & & 0.75 & $\begin{array}{l}\text { Congratulations, for example: } \\
\text { "Good job!" }\end{array}$ \\
\hline & & & & & "Good job! You're very attentive!" \\
\hline & \multirow{3}{*}{$\begin{array}{c}\text { Non-verbal } \\
\text { congratulations }\end{array}$} & & & 0.59 & $\begin{array}{l}\text { He gives you signs (applause, } \\
\text { thumbs up) to congratulate you. }\end{array}$ \\
\hline & & & & 0.51 & $\begin{array}{l}\text { He has positive attitudes } \\
\text { (he smiles, pats your shoulder) } \\
\text { to say that it is good. }\end{array}$ \\
\hline & & & & 0.58 & $\begin{array}{l}\text { He nods his head } \\
\text { ("Yes" movement) to approve } \\
\text { what you have just succeeded. }\end{array}$ \\
\hline \multirow{3}{*}{ Factor 2} & \multirow{3}{*}{$\begin{array}{c}\text { No } \\
\text { reinforcement } \\
\text { case Success }\end{array}$} & \multirow{3}{*}{2.16} & \multirow{3}{*}{5} & 0.69 & He ignores your successes \\
\hline & & & & 0.68 & $\begin{array}{l}\text { He doesn't tell you anything } \\
\text { about your good performance. }\end{array}$ \\
\hline & & & & 0.70 & He doesn't tell you much. \\
\hline \multirow{3}{*}{ Factor 3} & \multirow{3}{*}{$\begin{array}{l}\text { The pupil } \\
\text { initiates: } \\
\text { show his } \\
\text { achievements }\end{array}$} & \multirow{3}{*}{2.13} & \multirow{3}{*}{6} & 0.75 & $\begin{array}{l}\text { You call your teacher to } \\
\text { show him your progress. }\end{array}$ \\
\hline & & & & 0.68 & $\begin{array}{l}\text { Tell your teacher that you are } \\
\text { coming. }\end{array}$ \\
\hline & & & & 0.72 & $\begin{array}{l}\text { You often call him to present } \\
\text { to him what you now know } \\
\text { how to do }\end{array}$ \\
\hline \multirow{3}{*}{ Factor 4} & \multirow{3}{*}{$\begin{array}{l}\text { Feedbacks } \\
\text { techniques }\end{array}$} & \multirow{3}{*}{3.45} & \multirow{3}{*}{11} & 0.67 & $\begin{array}{l}\text { Give you technical information } \\
\text { to help you, for example: } \\
\text { "Flex your legs more". }\end{array}$ \\
\hline & & & & 0.72 & $\begin{array}{l}\text { Advise you by giving you } \\
\text { technical-tactical solutions, } \\
\text { by example: "lift your ball". }\end{array}$ \\
\hline & & & & 0.74 & $\begin{array}{l}\text { Help you by telling you how to } \\
\text { do, for example: } \\
\text { "try to leave less quickly". }\end{array}$ \\
\hline
\end{tabular}




\section{Continued}

\begin{tabular}{|c|c|c|c|c|c|}
\hline & & & & 0.71 & $\begin{array}{l}\text { Guide you by giving you advice, } \\
\text { for example: "jump higher". }\end{array}$ \\
\hline \multirow{3}{*}{ Factor 5} & \multirow{3}{*}{ Encouragements } & \multirow{3}{*}{1.92} & \multirow{3}{*}{6} & 0.56 & $\begin{array}{l}\text { Encourage you, for example: } \\
\text { "You'll do better next time". }\end{array}$ \\
\hline & & & & 0.49 & $\begin{array}{l}\text { Supports you, for example: } \\
\text { "Try again!" }\end{array}$ \\
\hline & & & & 0.60 & $\begin{array}{l}\text { Assist you, for example: } \\
\text { "Continues, you'll get there!" }\end{array}$ \\
\hline \multirow{7}{*}{ Factor 5} & \multirow{7}{*}{$\begin{array}{l}\text { Verbal criticism } \\
\text { Reviews with } \\
\text { Feedback } \\
\text { Technical }\end{array}$} & \multirow{7}{*}{4.89} & \multirow{7}{*}{11} & 0.46 & $\begin{array}{l}\text { Tells you that what you did is not } \\
\text { good, for example: "Bad pass!" }\end{array}$ \\
\hline & & & & 0.77 & $\begin{array}{l}\text { Tells you the following things, } \\
\text { for example: "Poorly played!" } \\
\text { You're not trying hard enough! }\end{array}$ \\
\hline & & & & 0.60 & $\begin{array}{l}\text { Often tells you that what you } \\
\text { come to do is not good, } \\
\text { for example: } \\
\text { "Wrongly seen, it's not that!" }\end{array}$ \\
\hline & & & & 0.61 & $\begin{array}{l}\text { Tells you that you do not do the } \\
\text { maximum, for example: } \\
\text { "Do more of effort!" }\end{array}$ \\
\hline & & & & 0.49 & $\begin{array}{l}\text { Reproaches you and then advises } \\
\text { you, for example: "Missed again, } \\
\text { climb your elbow!" }\end{array}$ \\
\hline & & & & 0.46 & $\begin{array}{l}\text { Rebuke you, then help you, } \\
\text { for example "Bad pass, } \\
\text { shoots with both hands!" }\end{array}$ \\
\hline & & & & 0.67 & $\begin{array}{l}\text { Criticize you by telling you what } \\
\text { to do, for example: "It's not good, } \\
\text { stay attentive!" }\end{array}$ \\
\hline \multirow{4}{*}{ Factor 6} & \multirow{4}{*}{$\begin{array}{l}\text { non verbal } \\
\text { critics }\end{array}$} & & & 0.59 & $\begin{array}{l}\text { The teacher looks up while } \\
\text { looking at the sky }\end{array}$ \\
\hline & & & & 0.56 & $\begin{array}{l}\text { The teacher has negative attitudes } \\
\text { ("no" movement of the head) }\end{array}$ \\
\hline & & & & 0.58 & Teacher appears angry (frowns) \\
\hline & & & & 0.43 & $\begin{array}{l}\text { The teacher looks away and } \\
\text { looks at someone }\end{array}$ \\
\hline \multirow{3}{*}{ Factor 7} & \multirow{3}{*}{$\begin{array}{c}\text { No } \\
\text { reinforcement } \\
\text { in a situation } \\
\text { of failure }\end{array}$} & \multirow{3}{*}{0.79} & \multirow{3}{*}{2} & 0.28 & He does not know your mistakes \\
\hline & & & & 0.35 & $\begin{array}{l}\text { He does not tell you anything } \\
\text { about your bad performance }\end{array}$ \\
\hline & & & & 0.33 & He does not tell you much \\
\hline \multirow{3}{*}{ Factor 8} & \multirow{3}{*}{$\begin{array}{l}\text { Student } \\
\text { initiates: } \\
\text { ks for help } \\
\text { assistance }\end{array}$} & \multirow{3}{*}{3.56} & \multirow{3}{*}{7} & 0.82 & $\begin{array}{l}\text { You will see your teacher to give } \\
\text { you advice. }\end{array}$ \\
\hline & & & & 0.85 & $\begin{array}{l}\text { You often ask for advice from } \\
\text { your teacher. }\end{array}$ \\
\hline & & & & 0.83 & $\begin{array}{l}\text { Speak with your teacher to ask } \\
\text { him assistance }\end{array}$ \\
\hline
\end{tabular}


Table 2. Correlations between the student's characteristics and the feedback received by the student.

\begin{tabular}{|c|c|c|c|c|c|c|c|c|c|c|c|c|c|}
\hline & Variables & 1 & 2 & 3 & 4 & 5 & 6 & 7 & 8 & 9 & 10 & 11 & 12 \\
\hline \multicolumn{14}{|c|}{ Characteristics of the student } \\
\hline 1 & Sex of the student & 1.00 & -0.11 & -0.36 & -0.23 & 0.07 & 0.03 & 0.13 & 0.12 & 0.22 & 0.25 & -0.15 & 0.12 \\
\hline 2 & Out-of-School Practice & & 1.00 & 0.27 & 0.24 & 0.14 & 0.17 & -0.05 & 0.02 & 0.05 & 0.06 & -0.10 & 0.02 \\
\hline 3 & Physical Competence & & & 1.00 & 0.38 & 0.20 & 0.28 & -0.11 & 0.10 & -0.07 & -0.05 & -0.11 & 0.08 \\
\hline 4 & Level in PE & & & & 1.00 & 0.090 . & 0.08 & 0.03 & -0.06 & -0.16 & -0.12 & -0.19 & -0.07 \\
\hline 5 & Time invested & & & & & 1.00 & 0.53 & -0.42 & 0.24 & 0.370 & 0.41 & -0.10 & 0.34 \\
\hline \multicolumn{14}{|c|}{ B-Perceived feedback success situation } \\
\hline 6 & Congratulations & & & & & & 1.00 & -0.56 & 0.25 & 0.40 & 0.52 & -0.04 & 0.29 \\
\hline 7 & No reinforcement & & & & & & & 1.00 & -0.18 & -0.36 & -0.42 & 0.18 & -0.23 \\
\hline 8 & Solicit to show his good achievement & & & & & & & & 1.00 & 0.16 & 0.26 & 0.08 & 0.53 \\
\hline \multicolumn{14}{|c|}{ Failure situation } \\
\hline 9 & Technical Feedback & & & & & & & & & 1.00 & 0.65 & 0.01 & 0.27 \\
\hline 10 & Promotion & & & & & & & & & & 1.00 & 0.05 & 0.35 \\
\hline 11 & Critical & & & & & & & & & & & 1.00 & 0.01 \\
\hline \multirow[t]{3}{*}{12} & Requesting help & & & & & & & & & & & & 1.00 \\
\hline & $\mathrm{x}^{-}$ & & 2.67 & 4.10 & 13.21 & 3.83 & 3.32 & 3.12 & 2.23 & 4.34 & 3.87 & 3.10 & 2.21 \\
\hline & SD & & 1.92 & 1.27 & 3.01 & 1.11 & 1.15 & 1.30 & 1.28 & 1.24 & 1.28 & 1.07 & 1.48 \\
\hline
\end{tabular}

The correlations are shown in bold; X, mean; SD, standard deviation.

\subsection{Analysis of Pupils' Perceptions}

In PSE, students' perceptions are closely related to the teacher's behaviour, depending on whether the student is in a situation of success or failure. Also, these perceptions go hand-in with the time invested by the teacher to each pupil, the level of the pupil in PSE, his physical competence and his amount of practice according to the gender of the pupil.

The results obtained in Table 3 sur the perceptions between the pupils and the feedback of the teacher of PSE, show a highly significant difference of the simple effect of male sex for a perception of physical skills $[\mathrm{F}(1.110)=60.02 ; p<$ $0.001]$, the level in PSE $[\mathrm{F}(1,110)=16.70 ; p<0.001]$ and the amount of practice $[\mathrm{F}(1,110)=14.59, p<0.001]$.

\section{Discussion}

The purpose of the study is to measure student perceptions of the behavioral feedback of the PSE teacher. The results obtained in Table 1 show that all factors have an acceptable level of internal consistency, variance, and own value (Cronbach, 1951), with the exception of the 7th factor: no reinforcement in a failure situation $[\alpha=0.40$; variance $=2 \%$; own value $=0.79]$. As a result, this factor was not retained for the rest of the analysis. 
Table 3. Student perceptions and feedback from the PSE teacher.

\begin{tabular}{|c|c|c|c|c|}
\hline \multirow{2}{*}{\multicolumn{2}{|c|}{ Variables }} & Boys & Girls & \multirow{2}{*}{$\mathrm{F}(1,110)$} \\
\hline & & $\mathrm{X} \pm \mathrm{SD}$ & $\mathrm{X} \pm \mathrm{SD}$ & \\
\hline \multirow{3}{*}{ Success Situation } & Congratulations & $2.14 \pm 0.22$ & $2.36 \pm 0.17$ & 1.23 \\
\hline & No strength & $3.63 \pm 1.13$ & $3.10 \pm 0.44$ & $3.82^{*}$ \\
\hline & Solicited to show good performance & $1.23 \pm 0.41$ & $2.41 \pm 1.08$ & $5.20^{\star \star}$ \\
\hline \multirow{4}{*}{ Failure situation } & Feedback technique & $2.75 \pm 1.06$ & $4.70 \pm 1.12$ & $18.1^{* * *}$ \\
\hline & Encouragement & $1.05 \pm 0.25$ & $3.88 \pm 1.33$ & $16.11^{* * *}$ \\
\hline & Critical & $3.12 \pm 0.97$ & $2.91 \pm 0.98$ & $2.43^{*}$ \\
\hline & Request of aid & $2.64 \pm 0.54$ & $3.56 \pm 1.28$ & $9.40^{* *}$ \\
\hline \multicolumn{2}{|r|}{ Time invested } & $3.35 \pm 1.22$ & $3.42 \pm 1.22$ & 1.19 \\
\hline \multicolumn{2}{|r|}{ Physical Competency } & $4.61 \pm 0.29$ & $2.39 \pm 1.18$ & $60.02^{* * *}$ \\
\hline \multicolumn{2}{|r|}{ PE level } & $13.84 \pm 2.17$ & $10.4 \pm 2.07$ & $16.70^{* * *}$ \\
\hline \multicolumn{2}{|r|}{ Quantity of Practice } & $3.38 \pm 2.96$ & $1.26 \pm 0.75$ & $14.59^{\star * *}$ \\
\hline
\end{tabular}

$\mathrm{X}$, mean; SD, standard deviation; ${ }^{*}, p<0.05 ;{ }^{* *}, p<0.01 ;{ }^{* * *}, p<0.001$.

However, the positive results of other factors may be explained by the fact that the three dimensions proposed in the congratulatory and critical categories (verbal, verbal with technical and non-verbal information) do not seem to not be differentiated by the pupil. Because each item saturates on the corresponding factor, for example the three items evaluating the technical feedback saturate perfectly on because each item saturates on the corresponding factor, for example the three items evaluating the technical feedbacks saturate perfectly on the same factor named technical feedbacks.

The reading of the results obtained in Table 2 reveals that the physical competence, the PSE note and the teacher feedback received by the students are correlated with the student's gender, except for congratulations and time invested. However, in a successful situation the gender of the pupil is positively correlated with the student's solicitations $[r=0.12]$ and the non-reinforcement $[r=0.13]$. In a failure situation, sex is positively correlated with technical feedback $[\mathrm{r}=$ $0.22]$ and encouragement $[r=0.25]$, whereas it is negatively correlated with critics $[r=-0.15]$. In other words, when the boys fail, they receive more criticism than the girls. This may be explained by the fact that the boys are more solicited by the PE teacher and perceive to be more ignored when they succeed in PE achievement.

In this regard, the American Association of University Women (1992) showed that boys and girls really have different sporting experiences. Specifically, this women's association has noticed that boys are used as models twice as often, they raise the teacher's attention five times more frequently, and verbally intervene twelve times more than girls (Ambrose, 1996).

On the other hand, the gender of the pupil is negatively correlated with the perception of physical competence $[r=-0.36]$ and the level in $P E[r=-0.23]$. 
This can be explained by the fact that the boy pupil perceives himself more proficient in PE and has a better level in PE than the girl pupil. For Eccles and Blumenfeld (1985), this differentiated skill treatment affects the motivational or behavioral variables of girls. Obviously girls doubt more about their abilities in the sports field, but many believe that it is innate therefore irreparable. Their representation in PE, sports preferences are marked sexually, which is why girls perceive themselves as less successful and competent in sport (Eccles \& Harold, 1991). This differentiated socialization of competence arises in an acute way to the sport, so it is problematic in PE. As the sport sphere is traditionally associated with the masculine, the opportunities for sports practices offered to girls and boys are not the same.

With regard to physical competence, it appears positively correlated with congratulations $[r=0.28]$ and the time invested by the teacher $[r=0.20]$. In this respect, two interpretations are possible:

- The more the student has the skills, the more the teacher invests time with him and receives congratulations when he succeeds;

- The more the pupil perceives that the teacher invests time with him and congratulates him, the more he perceives himself competent.

Also, it must be admitted that the level of the pupil in PE is negatively correlated with his perceptions of technical feedback $[r=-016]$, encouragement $[r=$ $-0.12]$ and critics $[r=-0.19]$ received in a failed situation. We can say without reservation that the more the pupil perceives to receive technical feedback, encouragement and criticism, the less competent he perceives, the less competent the pupil is, the more the latter perceives receiving more technical feedback, of encouragement and criticism. In this regard, Sadker \& Sadker (1994) have shown in college classes that boys speak more, participate more and receive more teacher interactions than girls. These authors have also recurrently shown two types of gender differences:

- Quantitative differences (frequency of interactions), boys receive more attention from teachers (Jones \& Wheatley, 1990), and they are given more time in class than girls;

- Qualitative differences (quality of interactions: Boys receive more accolades, criticisms and remediation's than girls.

The results obtained in Table 3 on perceptions between girls, boys and PE teacher feedback show a highly significant difference in the simple effect of male sex for perceptions of physical skills $[\mathrm{F}(1,110)=60.02 ; p<0.001]$, the level in PE $[\mathrm{F}(1,110)=16.70 ; p<0.001]$ and the amount of practice $[\mathrm{F}(1,110)=14.59, p<$ $0.001]$. This behavior is probably explained by the fact that boys have a regular extracurricular sport practice which in reality affects the physical skills of boys [4.61 \pm 1.29 vs $2.39 \pm 1.18]$. In this regard, McKiddie and Maynard (1997) show that boys preferentially use sporting criteria such as performance results and the acquisition of new skills to estimate their skill level.

In other words, the extra-curricular sports practice of boys affects the perceived physical skill, unfortunately this is not the case in girls. This behaviour 
also confirms the idea that boys have other sources of information to improve their PE performance level [13.84 \pm 2.17 vs $10.41 \pm 2.07]$ through extracurricular sports investment.

In contrast, girls practice little or almost no sport compared to boys. They do not have this additional information, this is because they rely more on the information provided by the teacher of PE.

Indeed, these results are to be considered irrespective of the perception of physical competence that the pupil has of himself and of his level in PE. It is similarly true that our results support this hypothesis. That is to say, regardless of the level of PE students and their physical skills, girls perceive more technical feedback and encouragement.

With regard to the poor performance achieved by girls, we can say that girls receive more technical feedback $[4.70 \pm 1.12$ vs $2.75 \pm 1.06]$ and encouragement [3.88 \pm 1.33 vs $1.05 \pm 0.25]$. They are more demanding the teacher to show their good performances $[2.41 \pm 1.08$ vs1.23 \pm 0.41$]$, but also to ask for help in the event of a didactic obstacle [3.56 \pm 1.28 vs $2.64 \pm 0.54$ ]. On the other hand, boys perceive more criticism $[3.12 \pm 0.97$ vs $2.91 \pm 0.98]$ and they feel more neglected in success than girls.

In other words, the interactions initiated by the girls involve solicitations to ask for help in case of failure or to show their good accomplishments. And yet all students perceive the same amount of information and time investment on the part of the teacher. Only boys are less likely to claim the teacher. They've always learned to be independent. For them, asking the teacher appears to be a sign of incompetence, especially in the field of sport. However, boys feel more neglected by the teacher than girls in a successful situation.

Paradoxically, our results seem to contradict the studies conducted by DeVoe (1991), McBride (1990) and Davis (2000) who did not see a significant difference in the perceptions of girls and boys in Teacher's pedagogical interventions.

Nevertheless, several observational studies have obtained inconsistent results on congratulations. For evidence, Dunbar and O’Sullivan (1986), Griffin (1981) and MacDonald (1990) showed that girls receive less congratulation than boys in physical and athletic education. Unlike studies by observing teacher interactions, girls perceive significantly more technical feedbacks and encouragement than boys. This observation prompted us to question how it can be explained that girls perceive receiving more technical feedback and encouragement. This observation prompted us to wonder about the question of "how can one explain that girls perceive receiving more technical feedback and encouragement, regardless of their level of PE and their physical competence?"

To this question we replied on the pretext that PE teachers may have strengthened these types of feedback in greater quantities, because they generally perceive that girls are more in a driving problem than boys in PSE. Teachers did not provide more technical feedback and encouragement to girls. Only, the perception of receiving technical feedback and encouragement can implicitly imply 
that girls perceive themselves as less adept and less motivated in the physical and sports activity concerned.

Only the results concerning the perceptions of the critics corroborate the previous work on the observations. In accordance with recent evidence (Davis, 2000; Couchot-Schiex \& Trottin, 2004), boys are more criticized for both their performances and their behaviour.

Numerous works, notably those of Drudy and UiChatain (2002) in the pedagogical domain, have highlighted this result in a recurrent way. The perceptions raised refer to the critics perceived as a result of the student's performance and not the displayed behavior. In addition, the relative proportion of feedback distributed by the teacher should be questioned.

Indeed, the proportion of the different types of communications in the French PE study (Trouilloud, 2002) revealed this: Organizational communication (34.4\%), technical (33\%), positive evaluative (7.5\%), evaluative negative ( $8.6 \%)$, emotional Positive (8.2\%) and negative affective (7.9\%). This is to say that the differences perceived by the boys on the critics represent a relatively small proportion of the teacher's communications in PE. Indeed, the proportion of the different types of communication in the French study in PE (Trouilloud, 2002) revealed this: Organizational communication (34.4\%), technical (33\%), positive evaluative (7.5\%), evaluative negative (8.6\%), emotional positive (8.2\%) and negative affective (7.9\%). This is to say that the differences perceived by the boys on the critics represent a relatively small proportion of the teacher's communications in PE. However, these data show that the technical feedback represents a large proportion of the information issued by the teacher in contrast to the encouragement.

However, these data show that the technical feedback represents a large proportion of the information issued by the teacher in contrast to the encouragement.

Contrary to what can be expected, the girls say that they initiate more interaction with the teacher in the context of failure and success. In this regard, we asked the students, why the teacher of PE has no particular comment to make in the same didactic circumstances following the failures or the good performances of the boys. Indeed, the students responded by saying that the teacher was indifferent to the performances performed by the boys. Another answer is that the boys are not satisfied with the teacher's attention to their success, given that they invest more in $\mathrm{PE}$ and appear more proficient in sport than girls in a comparative way.

In view of the foregoing, the perceived competence of the pupils is relative to the potential effects of the extracurricular sports investment, the pupil's level in PE. No specific hypothesis has been formulated, which shows a close link between feedback and time with perceived competence, since student perceptions are mediators of teacher behaviors, which can affect the perceptions of oneself of the student.

Of course, our results also underline that girls seem more sensitive to teacher feedback than boys regardless of their PE level and their extracurricular sports 
investment. Our study also showed in girls that the perception of skill is better when:

Boys is not affected by feedback from the teacher. Therefore, they receive congratulations;

- The teacher invests time with them;

- They perceive receiving less technical feedback, criticism;

- They request the teacher to ask him for help in a situation of failure.

Contrary to what one might have wished, the perception of physical competence boys are indifferent or less assigned to the information provided by the teacher of PE. They use other sources of information such as athletes to assess their proficiency, PE performance and peer feedback (Horn \& Hasbrook, 1986).

In addition, many ethnographic works or gender-studies discourse studies confirm perceptions and decision-making by teachers mainly based on an essentialist and androcentric ideology. Girls in the male context of PE are, for teachers, "problems", lacking motivation, making no effort and being solely concerned about their appearance. The speech clearly reveals their "failure" in relation to what boys are, i.e. lack of courage, lack of skills and lack of physical qualities. Teachers are also at the origin of jokes about the abilities or morphology of their pupils or create subcontractions reinforcing stereotypes (Ronholt, 2002).

These findings (sexual stéréotypisation, dichotomization and naturalization of female or male competencies) have been established in many countries, regardless of whether the PE is taught in a mixed or unisex context (Berg \& Lalema, 2010; Davis, 2003; Garrett, 2004; Koca, 2009; Larsson, Fagreel, \& Redelius, 2009; Beyria \& Gomaa, 2010; Wright, 1996). All these authors question the practice of extracurricular sports, which is the sport of physical education and its support for physical and sports activity as a major factor.

However, the interpretation of our data must take into account certain limits. First, our study was carried out in the natural context of teaching physical education in the Congo. Consequently, the measurements carried out include certain margins of error linked to the uncontrolled degrees of freedom inherent in the context. Second, because of the reduced number of teachers surveyed, inter-teacher variability was undoubtedly a limiting factor. Third, taking into account students' self-esteem can contribute can be an important factor in studying students' perceptions of teachers' pedagogical strategies. It is in this context that a longer study in duration (observation of several teaching cycles) and with a larger population of teachers is being carried out. This should make it possible to better understand the learning climate established by the teacher, taking into account the motivation and perceptions of the students.

\section{Conclusion}

The study of student perceptions and feedback from the PE a teacher showed that most factors have an acceptable level of internal consistency. There is a perfect correlation between all the factors. 
Thus, the physical competence, the PE note and the teacher feedback received by the students are correlated to the student's gender, except congratulations and time invested. Similarly, pupils' perceptions of PE are closely related to the teacher's behavior (authority or autonomy), depending on whether the students are in a situation of failure or success. Also, these perceptions go hand-in with the time invested by the teacher to each pupil, the level of the pupil in PSE, his physical competence and his athletic practice according to the gender of the pupil.

\section{Conflicts of Interest}

The authors declare no conflicts of interest regarding the publication of this paper.

\section{References}

Allen, J. B., \& Howe, B. L. (1998). Player Ability, Coach Feedback, and Female Adolescent Athletes' Perceived Competence and Satisfaction. Journal of Sport and Exercise Psychology, 20, 280-299. https://doi.org/10.1123/jsep.20.3.280

Ambrose, M. W. (1996). Do You Cheat Girls? Learning, 25, 72-75.

American Association of University Women (1992). How Schools Shortchange Girls: A Study of Major Findings on Girls in Education. Washington DC: AAUW.

Amorose, A. J., \& Horn, T. S. (2000). Intrinsic Motivation: Relationships with Collegiate Athletes' Gender, Scholarship Status, and Perceptions of Their Coaches' Behavior. Journal of Sport and Exercise Psychology, 22, 63-84. https://doi.org/10.1123/jsep.22.1.63

Auster, C., \& McRone, M. (1994). The Classroom as a Negotiated Social Setting: An Empirical Study of the Effects of Faculty Members' Behavior on Students' Participation. Teaching Sociology, 22, 289-300. https://doi.org/10.2307/1318921

Berg, P., \& Lahelma, E. (2010). Gendering Processes in the Field of Physical Education. Gender and Education, 22, 31-46. https://doi.org/10.1080/09540250902748184

Beyria, F., \& Guerandel, C. (2010). La mixité dans les cours d'EPS d'un collège en ZEP: Entre distance et rapprochement des sexes. Revue Française de Pédagogie, 170, 17-30. https://doi.org/10.4000/rfp.1420

Brady, K. L., \& Eisler, R. M. (1999). Sex and Gender in the College Classroom: A Quantitative Analysis of Faculty-Student Interactions and Perceptions. Journal of Educational Psychology, 91, 127-145. https://doi.org/10.1037/0022-0663.91.1.127

Condravy, J., Skirboll, E., \& Taylor, R. (1998). Faculty Perceptions of Classroom Gender Dynamics. Women and Language, 21, 18-27. https://doi.org/10.1300/J014v18n04_02

Couchot-Schiex, S., \& Trottin, B. (2004). Interactions Enseignants/élèves en EPS: Variations en fonction du sexe et du genre. In G. Cogérino (Ed.), Filles et garçons en EPS (pp. 163-179). Paris: Editions Revue EPS.

Crawford, M., \& MacLeod, M. (1990). Gender in the College Classroom: An Assessment of the "Chilly Climate" for Women. Sex Roles, 23, 101-122. https://doi.org/10.1007/BF00289859

Cronbach, L. (1951). Coefficient Alpha and Internal Structure of Test. Psychometrical, 16, 296-334. https://doi.org/10.1007/BF02310555

David, B. (2000). Education Physique et sportive: La certification au baccalauréat. Paris: INRP. 
Davis, K. L. (2000). Qualitative Study of Gender Interactions between Teachers and Students in Selected High School Physical Education Classes. Dissertation Abstracts International, 61, 1338.

Davis, K. L. (2003). Teaching for Gender Equity in Physical Education: A Review of the Literature. Women in Sport and Physical Activity Journal, 12, 55-82. https://doi.org/10.1123/wspaj.12.2.55

DeVoe, D. E. (1991). Teacher Behavior Directed toward Individual Students in Elementary Physical Education. Journal of Classroom Interaction, 26, 9-14.

Drudy, S., \& ÚiChatháin, M. (2002). Gender Effects in Classroom Interaction: Data Collection, Self-Analysis, and Reflection. Evaluation and Research in Education, 16, 34-50. https://doi.org/10.1080/09500790208667005

Dunbar, R., \& O'Sullivan, M. (1986). Effects of Intervention on Differential Treatment of Boys and Girls in Elementary Physical Education Lessons. Journal of Teaching in Physical Education, 5, 166-175. https://doi.org/10.1123/jtpe.5.3.166

Eccles, J. S., \& Blumenfeld, P. (1985). Classroom Experiences and Student Gender: Are There Differences and Do They Matter? In L. C. Wilkinson, \& C. B. Marrett (Eds.), Gender Influences in Classroom Interaction (pp. 79-114). Orlando, FL: Academic Press Inc. https://doi.org/10.1016/B978-0-12-752075-9.50010-6

Eccles, J. S., \& Harold, R. (1991). Gender Differences in Sport Involvement: Applying the Eccles' Expectancy-Value Model. Journal of Applied Sport Psychology, 3, 7-35. https://doi.org/10.1080/10413209108406432

Garrett, R. (2004). Negotiating a Physical Identity: Girls, Bodies and Physical Education. Sport, Education and Society, 9, 223-237. https://doi.org/10.1080/1357332042000233958

Griffin, P. S. (1981). One Small Step for Person Kind: Observations and Suggestions for Sex Equality in Coeducational Physical Education Classes. Journal of Teaching in Physical Education, 1, 12-17. https://doi.org/10.1123/JTPE.1.s1.12

Guttman, L. (1954). Some Necessary Conditions for Common Factor Analysis. Psychometrika, 19, 149-185. https://doi.org/10.1007/BF02289162

Horn, T. S., \& Hasbrook, C. A. (1986). Informational Components Influencing Children's Perceptions of Their Physical Competence. In M. R. Weiss, \& D. Gould (Eds.), Proceedings of the 1984 Olympic Scientific Congress. Sport for Children and Youths (pp. 81-88). Champaign, IL: Human Kinetics.

Jenkins, M. M. et al. (1983). Removing Bias: Guidelines for Student-Faculty Communication (67 p.). Washington DC: Speech Communication Association, Annandale, VA: Women's Educational Equity Act Program (ED).

Jones, M. G., \& Wheatley, J. (1990). Gender Differences in Student-Teacher Interaction. Journal of Research in Science Teaching, 27, 861-874. https://doi.org/10.1002/tea.3660270906

Koca, C. (2009). Gender Interactions in Coed Physical Education: A Study in Turkey. Adolescence, 44, 165-185.

Larsson, H., Fagrell, B., \& Redelius, K. (2009). Queering Physical Education. Between Benevolence towards Girls and Tribute to Masculinity. Physical Education and Sport Pedagogy, 14, 1-17. https://doi.org/10.1080/17408980701345832

Le Ny, J. F. (2017). Encyclopedia universalis de l'Education. Paris: Editions ESF.

Mabassa, D.-S. (2015). Enseignement d'EPS: Influence du comportement de l'enseignant sur la motivation et les perceptions des élèves. Doctoral Dissertation (Unpblished), ENS, Chaire UNESCO, Université Marien NGOUABI. 
Macdonald, D. (1990). The Relationship between the Sex Composition of Physical Education Classes and Teacher-Pupil Verbal Interaction. Journal of Teaching in Physical Education, 9, 152-163. https://doi.org/10.1123/jtpe.9.2.152

McBride, R. E. (1990). Sex-Role Stereotyping Behaviours among Elementary, Junior, and Senior High School Physical Education Specialist. Journal of Teaching in Physical Education, 9, 249-261. https://doi.org/10.1123/jtpe.9.4.249

McKiddie, B., \& Maynard, I. W. (1997). Perceived Competence 1 of Schoolchildren in Physical Education. Journal of Teaching in Physical Education, 16, 324-339.

https://doi.org/10.1123/jtpe.16.3.324

Nadler, L., \& Nadler, M. (1990). Perceptions of Sex Differences in Classroom Communication. Women's Studies in Communication, 13, 46-65. https://doi.org/10.1080/07491409.1990.11089740

Ria, L. (2014). La pédagogie de l'éducation physique en question. De la théorie à la pratique. Paris: Armand Colin.

Ronholt, H. (2002). It's Only the Sissies...: Analysis of Teaching and Learning Process in Physical Education: A Contribution to the Hidden Curriculum. Sport, Education and Society, 7, 25-36. https://doi.org/10.1080/13573320120113558

Sadker, M., \& Sadker, D. (1994). Failing at Fairness: How America's Schools Cheat Girls. New York: MacMillan.

Sarrazin, P., Famose, J. P., \& Cury, F. (1995). But motivationnel, habileté perçue et sélection d'un niveau de difficulté d'une voie en escalade. STAPS, 38, 49-61.

Smith, R. E., Smoll, F. L., \& Hunt, E. B. (1977). A System for the Behavioural Assessment of Athletic Coach. Research Quarterly for Exercise and Sport, 48, 401-407. https://doi.org/10.1080/10671315.1977.10615438

Trouilloud, D. (2002). L'effet Pygmalion en Education Physique et Sportive. Réalité, processus médiateurs et variables modératrices de l'influence des attentes de l'enseignant sur la motivation et la performance des élèves. Thèse STAPS, non publiée, Université de Grenoble.

Wright, J. (1996). The Construction of Complementarity in Physical Education. Gender and Education, 8, 61-69. https://doi.org/10.1080/713668480 